\title{
The Effect of Administrative Services on Students' Satisfaction
}

\author{
Radia Elina $^{1 凶}$, Hafulyon ${ }^{2}$ \\ Manajemen Pendidikan Islam, Institut Agama Islam Negeri Batusangkar, Indonesia ${ }^{1,2}$ \\ email: radiaelina2106@gmail.com ${ }^{1}$, hafulyon@iainbatusangkar.ac.id ${ }^{2}$
}

\begin{tabular}{ll}
\hline Article info & \multicolumn{1}{c}{ Abstract } \\
\hline & This study aims to describe the effect of administrative personnel services on \\
Article History & students' satisfaction. This was a descriptive quantitative research that involved \\
Recieved: & 110 students of state junior high schools in Solok as the sample. Data were \\
$07 / 03 / 2021$ & collected using a questionnaire that was constructed based on related theories. \\
Accepted: & The data analysis included testing validity, testing reliability, descriptive analysis, \\
$04 / 05 / 2021$ & and simple linear regression. The findings described that there was no significant \\
Published: & relationship between the quality of administrative services and students' \\
$10 / 05 / 2021$ & satisfaction. It indicates that administrative services should pay attention to \\
& several aspects including tangibles, reliability, responsibility, assurance, and \\
& empathy to achieve students' satisfaction.
\end{tabular}

Corresponding author

Keywords: Administrative Services, Student Satisfaction

\begin{abstract}
Abstrak
Penelitian ini bertujuan untuk mengetahui pengaruh kualitas layanan tenaga administrasi terhadap kepuasan peserta didik. Penelitian menggunakan metode deskriptif kuantitatif dengan sampel penelitian sebanyak 110 peserta didik sekolah menengah pertama negeri Kota Solok. Teknik pengumpulan data menggunakan angket/kusioner yang disusun peneliti berdasarkan kajian teori. Teknik analisis data menggunakan uji validitas, uji reliabilitas, analisis descripsi, dan regsesi linier sederhana. Hasil penelitian ini ditemukan bahwa tidak terdapat hubungan yang signifikan antara kualitas layanan administrasi dengan kepuasan peserta didik. Temuan ini mengindikasikan bahwa dalam mencapai kepuasan peserta didik dalam layanan administrasi harus memperhatikan aspek Tangibles (Bukti Fisik), Reliability (Keandalan), Responsibility (Daya Tanggap), Assurance (Pengetahuan, kemampuan, kesopanan dan sifat percaya), dan Empathy (Komunikasi).
\end{abstract}

Kata Kunci: Kualitas Layanan Administrasi; Kepuasan Peserta Didik

JIES is licensed under a Creative Commons Atribution-Share Alike 4.0 Internasional Licence

\section{PENDAHULUAN}

Pendidikan merupakan salah satu alat untuk mencerdaskan sebuah bangsa atau Negara. Pendidikan merupakan sebuah media yang paling efektif untuk mengubah pemikiran manusia (Nurkholis, 2013). Pendidikan juga merupakan sarana utama yang harus dikelola secara sistematis dan secara konsisten dengan mengikuti perkembangan zaman dalam kehidupan. Perkembangan zaman di tandai dengan perkembangan ilmu pengetahuan dan teknologi. Perkembangan ilmu pengetahuan dan teknologi tersebut bisa dilihat dari pendidikan yang berlangsung di sekolah (Hudiarini, 2017). 
Setiap lembaga pendidikan di minta untuk dapat memenuhi keinginan dan kebutuhan pelanggannya. Keberhasilan dalam pendidikan bisa dilihat salah satunya dari kepuasan peserta didik (Komarudin \& Subekti, 2021; Kusumawardhani \& Burhanuddin, 2020; Maisaroh, 2005). Hal tersebut sejalan dengan penelitian Kusjono \& Sudjiani, (2019), menyebutkan bahwa "kualitas layanan mempunyai pengaruh positif terhadap kepuasan peserta didik. Oleh karena itu, perlu dipertahankan kualitas layanan yang sudah baik dalam peningkatan kepuasan peserta didik dengan cara mempertahankan keandalan (reability) layanan dan meningkatkan daya tanggap (responsiveness) layanan terhadap kepuasan peserta didik".

Kualitas layanan bergantung pada peranan pegawainya dalam upayanya memberikan cara kerja terbaik untuk memperoleh kepuasan bagi pelanggannya dalam hal ini peserta didik (Purmadi \& Garnika, 2019; Utami et al., 2018). Hal ini sejalan dengan penelitian Hayanti et al., (2019), yang menyebutkan bahwa lembaga pendidikan yang memiliki pelayanan berkualitas dari pegawainya maka pelanggan akan mendapatkan kepuasan sehingga timbul kepercayaan dan kenyamanan

Faktor-faktor yang dapat memberikan pengaruh kepuasan konsumen dapat diukur melalui Tangibles (Bukti Fisik), Reliability (Keandalan), Responsibility (Daya Tanggap), Assurance (Pengetahuan, kemampuan, kesopanan dan sifat percaya), dan Empathy (Komunikasi) (Santi \& Huda, 2015). Dimana keseluruhan aspek tersebut merupakan komponen yang sangat diperlukan dalam melaksanakan pelayanan yang baik, efektif dan efisien. Dalam hal ini, kemampuan manejerial dalam meningkatkan kualitas layanan merupakan suatu peran yang paling penting, agar semua diharapkan dapat terpenuhi.

Kunci kualitas layanan yaitu mampu melebihi dari harapan kualitas pelayanan pelanggan sasaran. Kualitas diartikan sebagai pernyataan sikap, relasi yang didapatkan dengan cara membandingkan harapan dengan kinerja, sehingga dapat meningkatkan mutu organisasi yang didudukinya (Faizal, 2012). Dalam kenyataan tersebut, penelitian yang dilakukan oleh Azhar (2015), sekolah sebagai penyedia jasa pendidikan harus bertransformasi dalam pemberian pelayanan agar mendapatkan pengakuan oleh pengguna serta berdaya saing. Layanan pendidikan tersebut terdiri dari lima jenis jasa pokok pelayanan yaitu: pelayanan administrasi pendidikan, penelitian, kurikuler, pembelajaran, dan informasi pendidikan.

Dalam administrasi pendidikan pada intinya merupakan suatu bentuk kegiatan secara produktif dalam mencapai tujuan pendidikan yang efektif dan efisien. Oleh karena itu dalam mengukur keberhasilan sistem administrasi pendidikan yaitu tampak dari produktivitas berupa prestasi untuk mencapai keadaan yang efisien. Efektivitas tampak dari input yang merata, keluaran yang bermutu tinggi dan memadai sesuai dengan kebutuhan di masyarakat (Moh Fahmi Amrizal, 2020).

Pengelola yang berhasil dalam menangani administrasi sekolah maka keberhasilan juga akan didapatkan dalam pencapaian tujuan pendidikan. Tanpa administrasi yang berjalan dengan baik makan tidak akan dapat mewujudkan tujuan pendidikan yang 
optimal. Berdasarkan teori yang dijabarkan di atas, bisa dilihat di SMPN 2 Kota Solok pada umumnya lulusan SMPN 2 Kota Solok melanjutkan pendidikannya ke sekolah unggulan baik di kota Solok itu sendiri maupun di luar Kota Solok. Feed back dari masyarakat positif akan hal itu terhadap sekolah sehingga banyak orang tua berbondong-bodong memasukkan anaknya bersekolah.

Penelitian yang telah diteliti oleh peneliti sebelumnya menyebutkan bahwa kepuasan peserta didik bergantung pada kualitas layanan administrasi, oleh karena itu penelitian ini mencoba melihat hubungan yang terdapat dari kualitas layanan administrasi yang diperoleh peserta didik terhadap kepuasan peserta didik.

\section{METODE PENELITIAN}

Penelitian ini menggunakan pendekatan kuantitatif deskriptif yang bertujuan untuk mengkaji pengaruh kualitas pelayanan administrasi terhadap kepuasan peserta didik, dan kendala yang dihadapi dalam melaksanakan pelayanan administrasi pada SMPN 2 Kota Solok. Penggunaan metode kuantitatif ini dimaksudkan untuk mendapatkan sejauh mana kualitas dan pemahaman yang lebih luas dan mendalam terhadap data yang ditemukan dan dihadapi peneliti. Peneliti menggunakan pendekatan kuantitatif deskriptif karena permasalahan kuantitatif layanan administrasi terhadap kepuasan peserta didik di SMPN 2 Kota Solok berkenaan dengan angka-angka beserta penjelasan yang di ambil dari perhitungan statistik.

Populasi pada penelitian ini adalah seluruh peserta didik di SMPN 2 Kota Solok dan penarikan sampel pada penelitian menggunakan simple random sampling sehinnga diperoleh 110 responden peserta didik. Teknik pengumpulan data menggunakan angket/ kusioner. Teknik analisis data yang digunakan dalam penelitian ini adalah uji validitas, uji reliabilitas, Uji Normalitas, Uji t, Uji Determinan analisis descripsi, Analisis Product Moment dan regsesi linier sederhana.

\section{HASIL DAN PEMBAHASAN}

Analisis deskripsi pada skala kualitas layanan administrasi dapat dilihat dari tabel berikut:

Tabel 1. Descriptive Statistics

Kualitas Layanan Administrasi

\begin{tabular}{lrrrrr}
\hline & N & Minimum & Maximum & Mean & Std. Deviation \\
Total Pelayanan & 110 & 87 & 146 & 119,07 & 9,642 \\
\hline Valid N (listwise) & 110 & & & & \\
\hline
\end{tabular}

Pada tabel 1 di atas, memperlihatkan kesimpulan deskripsi data mengenai variabel $(\mathrm{X})$ yaitu Kualitas layanan administrasi. Dalam tabel di atas terlihat subjek yang diteliti sebanyak 110 responden. Penjabaran deskripsi data yang diperoleh nilai terendah (minimum) sebesar 87, nilai tertinggi (maximum) sebesar 146, nilai rata-rata (mean) yang diperoleh 119.07 dan standar devisiasi 9,642. 
Tabel 2. Descriptive Statistics Kepuasan Peserta Didik

\begin{tabular}{lcccccc}
\hline & N & Minimum & Maximum & Mean & \multicolumn{2}{c}{ Std. Deviation } \\
\hline Total Pelayanan & 110 & 30 & 50 & 39,47 & 4,233 \\
\hline Valid N (listwise) & 110 & \multicolumn{3}{c}{} \\
\hline
\end{tabular}

Analisis deskripsi mengenai variabel dependen (Y) yaitu kepuasan peserta didik dengan dapat diketahui subjek yang diteliti sebanyak 110 responden. Penjabaran deskripsi data yang diperoleh nilai terendah (minimum) sebesar 30, nilai tertinggi (maximum) sebesar 50, nilai rata-rata (mean) yang diperoleh 39,47 dan standar devisiasi 4,233 .

Tabel 3. Koefisien Determinan Model Summary

\begin{tabular}{lcccr}
\hline Model & R & R Square & $\begin{array}{c}\text { Adjusted R } \\
\text { Square }\end{array}$ & $\begin{array}{c}\text { Std. Error of } \\
\text { the Estimate }\end{array}$ \\
\hline 1 &, $566^{\mathrm{a}}$ &, 320 &, 288 & 3,573 \\
\hline a. Predictors: (Constant), Total Emphaty, Total Responsiveness, \\
Total Assurance, Total Tangibles, Total Reliability
\end{tabular}

Tabel diatas mengandung besarnya nilai korelasi atau hubungan (R) yaitu sebesar 0,556. Dari output tersebut diperoleh koefisien determinasi (R Square) sebesar 0,320, yang mengandung arti bahwa pengaruh variabel bebas (Kualitas Layanan Administrasi) terhadap variabel terikat (Kepuasan Peserta Didik) sebesar 0,320. Hal ini menunjukkan bahwa adanya keterlibatan kualitas layanan administrasi terhadap kepuasan peserta didik sebesar 0,320. Sedangkan 1,00-0,320=0,68 lainnya dipengaruhi oleh faktor lain di luar variabel yang diteliti.

Tabel 4. Uji F ANOVA ${ }^{\mathrm{a}}$

\begin{tabular}{llcrrrr}
\hline \multirow{2}{*}{ Model } & & $\begin{array}{c}\text { Sum of } \\
\text { Squares }\end{array}$ & Df & $\begin{array}{c}\text { Mean } \\
\text { Square }\end{array}$ & F & Sig. \\
\hline 1 & Regression & 625,883 & 5 & 125,177 & 9,806 &, 000 \\
& & & & & & \\
\cline { 2 - 7 } & & 1327,535 & 104 & 12,765 & & \\
\cline { 2 - 7 } & Residual & 1953,418 & 109 & & & \\
\cline { 2 - 7 } & Total & 195,4 & & &
\end{tabular}

a. Dependent Variable: KepuasanPesertaDidik

b. Predictors: (Constant), TotalEmphaty, TotalResponsiveness,

TotalAssurance, TotalTangibles, TotalReliability

Berdasarkan dari output diatas dapat dilihat nilai $\mathrm{F}$ hitung adalah 9,806 dengan tingkat signifikan sebesar $0,00<0,05$, berarti dapat dikatakan adanya pengaruh positif yang signifikan antara variabel $(\mathrm{X})$ yaitu kualitas layanan administrasi dengan variabel (Y) kepuasan peserta didik. Untuk mengetahui korelasi antara kualitas layanan administrasi terhadap kepuasan peserta didik dalam uji hipotesis korelasi produk momen yang dijelaskan pada tabel berikut: 
Tabel 5. Uji Correlations Produk Moment

\begin{tabular}{llrr}
\hline & & $\begin{array}{c}\text { Kualitas } \\
\text { Pelayanan } \\
\text { Administrasi }\end{array}$ & $\begin{array}{c}\text { Kepuasan } \\
\text { Peserta Didik }\end{array}$ \\
\hline $\begin{array}{l}\text { KualitasPelayananAd } \\
\text { ministrasi }\end{array}$ & $\begin{array}{l}\text { Pearson } \\
\text { Correlation }\end{array}$ & 1 &, 092 \\
& Sig. (2-tailed) & &, 342 \\
& $\mathrm{~N}$ & 110 & 110 \\
\hline KepuasanPesertaDidik & Pearson &, 092 & 1 \\
& Correlation & & \\
& Sig. (2-tailed) &, 342 & 110 \\
& $\mathrm{~N}$ & 110 & \\
\hline
\end{tabular}

Koefisien korelasi sebesar 0,092 dengan taraf signifikan 0,342>0,05, artinya tidak terdapat hubungan yang signifikan antara kualitas layanan administrasi terhadap kepuasan peserta didik di SMPN 2 Kota Solok. Untuk melihat hubungan antara variabel kualitas layanan administrasi $(\mathrm{X})$ terhadap variabel kepuasan peserta didik (Y) memiliki correlation 0,092 dengan membandingkan dengan nilai $\mathrm{r}$ tabel yaitu 0,195 besar dari hasil. Maka dapat dinyatakan tidak terdapatnya hubungan antara variabel (X) dengan variabel (Y).

Untuk pengambilan keputusan dalam uji regresi linier sederhana, dapat dilihat dari nilai t. berdasarkan nilai t: diketahui t hitung sebesar 0,955 < t tabel 1,965, sehingga dapat disimpulkan bahwa variabel $(\mathrm{X})$ tidak berpengaruh signifikan terhadap Variabel (Y).

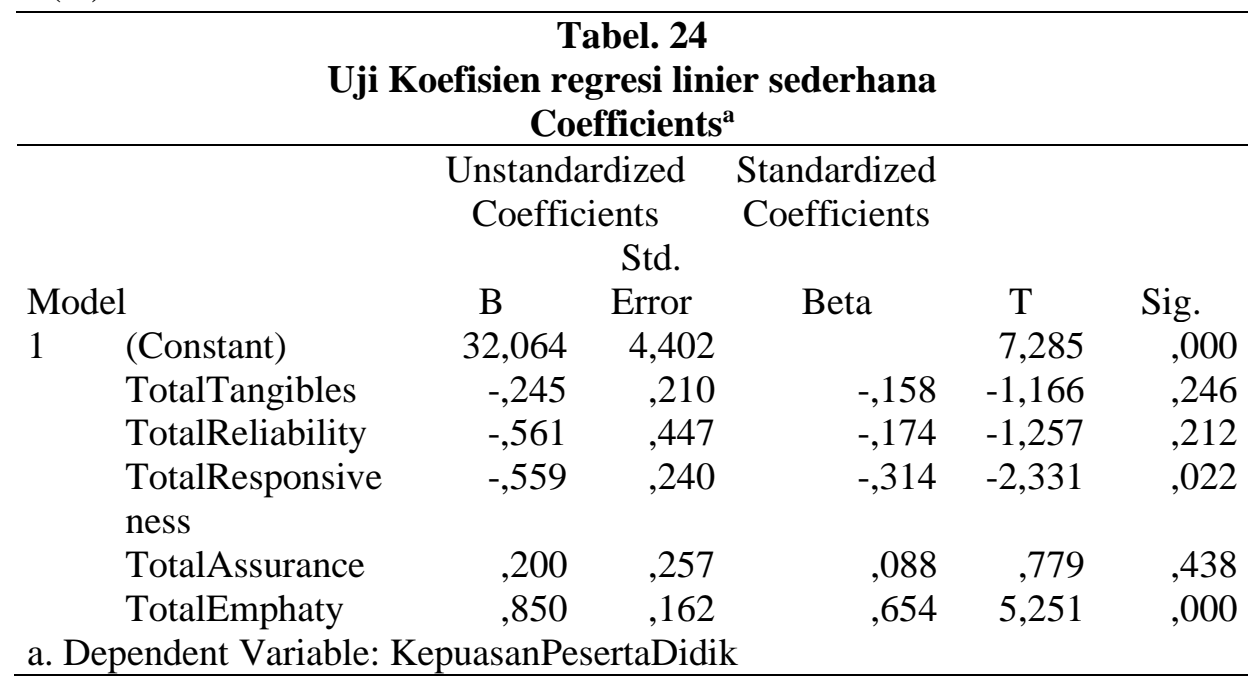

Pada tabel diatas menunjukkan nilai signifikan dari variabel $(\mathrm{X})$ yang terbagi atas beberapa indikator yang dimulai dari :

a. Tangibles (Bentuk Fisik)

Pada tabel.24 menunjukkan nilai signifikan dari tangibles yaitu sebesar 0,246 yang berarti nilai signifikan tersebut lebih besar dari nilai probabilitas yaitu 0,05 atau dapat dibikin seperti nilai $0,246>0,05$. Sehingga, dari pernyataan di atas dapat 
dikatakan kalau indikator tangibles tidak berpengaruh positif yang signifikan dengan kepuasan peserta didik.

\section{b. Reliability}

Pada tabel menunjukkan nilai signifikan dari reliability yaitu sebesar 0,212 yang berarti nilai signifikan tersebut lebih besar dari nilai probabilitas yaitu 0,05 atau dapat dibikin seperti nilai $0,212>0,05$. Sehingga, dari pernyataan di atas dapat dikatakan kalau indikator reliability tidak berpengaruh positif yang signifikan dengan kepuasan peserta didik.

c. Responsiveness

Pada tabel menunjukkan nilai signifikan dari responiveness yaitu sebesar 0,022 yang berarti nilai signifikan tersebut lebih besar dari nilai probabilitas yaitu 0,05 atau dapat dibikin seperti nilai $0,022>0,05$. Sehingga, dari pernyataan di atas dapat dikatakan kalau indikator responsiveness tidak berpengaruh positif yang signifikan dengan kepuasan peserta didik.

\section{d. Assurance}

Pada tabel menunjukkan nilai signifikan dari assurance yaitu sebesar 0,438 yang berarti nilai signifikan tersebut lebih besar dari nilai probabilitas yaitu 0,05 atau dapat dibikin seperti nilai $0,438>0,05$. Sehingga, dari pernyataan diatas dapat dikatakan kalau indikator assurance tidak berpengaruh positif yang signifikan dengan kepuasan peserta didik.

e. Emphaty

Pada tabel menunjukkan nilai signifikan dari Emphaty yaitu sebesar 0,00 yang berarti nilai signifikan tersebut lebih besar dari nilai probabilitas yaitu 0,05 atau dapat dibikin seperti nilai $0,000<0,05$. Sehingga, dari pernyataan di atas dapat dikatakan kalau indikator emphaty terdapat berpengaruh positif yang signifikan dengan kepuasan peserta didik.

\section{Tabel. 25}

Regresi Linier Sederhana

Coefficients $^{\mathbf{a}}$

\begin{tabular}{|c|c|c|c|c|c|}
\hline \multirow[b]{2}{*}{ Model } & \multicolumn{2}{|c|}{$\begin{array}{c}\text { Unstandardized } \\
\text { Coefficients } \\
\text { Std. }\end{array}$} & \multicolumn{3}{|l|}{$\begin{array}{l}\text { Standardized } \\
\text { Coefficients }\end{array}$} \\
\hline & B & $\begin{array}{l}\text { Std. } \\
\text { Error }\end{array}$ & Beta & $\mathrm{T}$ & Sig. \\
\hline (Constant) & 34,688 & 5,026 & & 6,902 &, 000 \\
\hline $\begin{array}{l}\text { KualitasPelayananAd } \\
\text { ministrasi }\end{array}$ & ,040 &, 042 & ,092 & ,955 &, 342 \\
\hline
\end{tabular}

a. Dependent Variable: Kepuasan Peserta Didik

Pada tabel diatas, menunjukkan nilai constant (a) sebesar 34,688, sedangkan nilai kualitas pelayanan administrasinya sebesar (b/koefisien) 0,040, sehingga jikalau dimasukkan kedalam persamaan regresinya berupa:

$$
Y=a+b=34,688+0,40 \mathrm{x}
$$


Dari persamaan diatas dapat dijelaskan beberapa hal:

1. Konstanta sebesar 34,688 yang mengandung arti nilai konsisten variabel kepuasan peserta didik sebesar 34,688.

2. Koefisien regresi $X$ sebesar 0,40 menyatakan bahwa setiap penambahan $1 \%$ nilai kualitas layanan administrasi, maka nilai kepuasan peserta didik bertambah sebesar 0,40. Koefisien regresi tersebut bernilai positif, sehingga dapat dikatakan arah variabel X terhadap Y adalah Positif. Dengan kata lain, semakin banyak baik kualitas layanan administrasi maka kepuasan peserta didik juga akan meningkat.

Temuan penelitian ini menunjukkan bahwa dalam sub variabel Tangibles terhadap kepuasan peserta didik menunjukkan hasil tidak terdapat hubungan yang signifikan dengan kepuasan peserta didik yang berkaitan dengan bukti fisik meliputi fasilitas fisik, perlengkapan pegawai, sarana komunikasi, dan alat-alat komputer, serta tampilan dari seragam karyawan. Tingkat kelengkapan peralatan atau teknologi yang digunakan akan dapat berpengaruh pada pandangan peserta didik akan kesiapan SMPN 2 Kota Solok dalam memberikan pelayanan. Begitu juga dengan indikator reliability, daya tanggap (responsiveness) dan Jaminan (assurance) tidak terdapat hubungan yang signifikan dengan kepuasan peserta didik. Namun pada aspek empat terdapat pengaruh hubungan yang signifikan dengan kepuasan peserta didik dengan demikian terdapat kemudahan untuk melakukan jalinan hubungan, komunikasi yang baik, perhatian pribadi, dan pemahaman atas kebutuhan individual para peserta didik dengan stakeholder yang ada di sekolah.

Penelitian ini sejalan dengan penelitian Sya'diah \& Purwanti (2019), secara umum penelitian ini menunjukkan bahwa penelitian variabel responden terhadap variabel-variabel penelitian sudah cukup baik. Hasil tersebut juga sejalan dengan penelitian yang dilakukan oleh Hasbi (2018), yang menemukan bahwa empati merupakan bagian dari kualitas pelayanan administrasi yang sangat berpengaruh secara signifikan dalam hal kepuasan peserta didik. Hal tersebut juga di dukung oleh kajian penelitian oleh yang menunjukkan kualitas pelayanan dan fasilitas fisik berpengaruh positif dan signifikan terhadap kepuasan mahasiswa

Hasil penelitian lain Sudodo, (2017) juga menyebutkan bahwa "layanan keandalan, responsif, jaminan, empati, dan nyata berpengaruh secara signifikan terhadap kepuasan siswa". Kualitas pelayanan merupakan tingkat keunggulan yang diharapkan dan pengendalian atas tingkat keunggulan untuk memenuhi harapan konsumen. Kualitas layanan administrasi ini sendiri adalah nilai kualitas dari pegawai yang diharapkan oleh konsumen dalam bidang administrasi. Sehingga menurut Natalia et al., (2020), menjelaskan bahwa seberapa efektif dan efisien usaha dalam pencapaian tujuan dari pendidikan yang terintegrasi

Gani \& Hasan (2019), menyebutkan bahwa kualitas layanan diukur dari seberapa baik ekspektasi pelanggan berbanding lurus dengan pemberian layanan. Harapan yang tidak sesuai dengan kenyataan, maka image buruk akan dicitrakan oleh pelanggan terhadap kualitas jasa yang di berikan, begitu juga sebaliknya harapan 
konsumen terlampai terhadap ekspektasi yang diperoleh, maka citra ideal akan ter citrakan dari kualitas jasa. Dengan demikian, kualitas jasa bergantung dari bagaimana kesanggupan penyedia jasa dapat memberikan harapan pelanggannya dengan konsisten.

\section{KESIMPULAN}

Temuan penelitian ini menunjukkan bahwa hubungan antara kualitas layanan administrasi dengan kepuasan peserta didik tidak terdapat hubungan yang signifikan. Di antara kelima aspek variabel kepuasan peserta didik terhadap kualitas layanan administrasi terdapat empat aspek yang tidak memiliki nilai koefisien berpengaruh positif yang signifikan yaitu aspek Tangibles (Bukti Fisik), Reliability (Keandalan), Responsibility (Daya Tanggap), Assurance (Pengetahuan, kemampuan, kesopanan dan sifat percaya). Sementara aspek empati memiliki nilai koefisien berpengaruh positif yang signifikan dengan kepuasan peserta didik. Dengan demikian perlu peningkatan kepuasan peserta didik melalui peningkatan aspek-aspek dari kualitas layanan administrasi yang terdapat di sekolah.

\section{DAFTAR PUSTAKA}

Azhar, Z. A. (2015). Analisis Tingkat Kepuasan Peserta Didik Terhadap Institusi Pendidikan. JIAFE (Jurnal Ilmiah Akuntansi Fakultas Ekonomi), 1(1), 44-58. https://doi.org/10.34204/jiafe.v1i1.296

Faizal, I. (2012). Dampak Kualitas Pelayanan Jasa Pendidikan Terhadap Kepuasan Peserta Didik Pada Jurusan Keselamatan Penerbangan Di Stpi-Curug. Jurnal Aviasi Langit Biru, 5(11), 1-15.

Gani, M., \& Hasan, S. (2019). Pengaruh Kualitas Layanan Terhadap Kepuasan Peserta Didik SMP dan SMA Islam Terpadu. Pengaruh Kualitas Layanan, 2(2).

Hasbi, M. (2018). Pengaruh Kualitas Pelayanan Administrasi terhadap Kepuasan Peserta Didik di MTs Negeri 1 Model Palembang. Manageria Jurnal Manajemen Pendidikan Islam, 3(1), 87-109. https://doi.org/10.14421/manageria.2018.31-05

Hayanti, A. T., Suryani, N., \& Rozi, F. (2019). Pengaruh Kualitas Pelayanan, Citra Sekolah, dan Emosional Terhadap Kepuasan Peserta Didik. Economic Education Analysis Journal, 8(3), 1260-1274. https://doi.org/10.15294/eeaj.v8i3.34955

Hudiarini, S. (2017). Penyertaan etika bagi masyarakat akademik di kalangan dunia pendidikan tinggi. Jurnal Moral Kemasyarakatan, 2(1), 1-13.

Komarudin, K., \& Subekti, B. H. (2021). Tingkat Kepuasan Peserta Didik Terhadap Pembelajaran Pjok Daring. Jambura Health and Sport Journal, 3(1), 16-23. https://doi.org/10.37311/jhsj.v3i1.9847

Kusjono, G., \& Sudjiani, E. (2019). Pengaruh Kualitas Layanan Pendidikan Terhadap Kepuasan Peserta Didik Di Sma Islam Cikal Harapan Bumi Serpong Damai. Jurnal Ilmiah Feasible (JIF), 1(1), 83. https://doi.org/10.32493/fb.v1i1.2019.83- 
94.2269

Kusumawardhani, D. A., \& Burhanuddin, B. (2020). Analisis Kepuasan Peserta Didik Terhadap Layanan Evaluasi Hasil Belajar Online. Jurnal Administrasi Dan Manajemen Pendidikan, 3(1), 90-101. https://doi.org/10.17977/um027v3i12020p90

Maisaroh, S. (2005). Pengaruh Manajemen Mutu Layanan terhadap Kepuasan Peserta Didik di Universitas PGRI Yogyakarta. Laporan Penelitian. Universitas PGRI Yogyakarta.

Moh Fahmi Amrizal, G. D. L. (2020). Hubungan Antara Pengelolaan Pembelajaran Dengan Tingkat Kepuasan Peserta Didik Di Lembaga Bimbingan Belajar Plus Ilhami. Jurnal Pendidikan Untuk Semua, 04(1), 40-50.

Natalia, I., Nurhayati, N., \& Apria, E. (2020). Kualitas Pelayanan Dan Fasilitas Fisik Terhadap Kepuasan Peserta Didik (Studi Pada LP3I College Purwakarta). JAB (Jurnal Akuntansi \& Bisnis), 6(1). www.journal.uta45jakarta.ac.id

Nurkholis, N. (2013). Pendidikan Dalam Upaya Memajukan Teknologi. Jurnal Kependidikan, 1(1), 24-44. https://doi.org/10.24090/jk.v1i1.530

Purmadi, A., \& Garnika, E. (2019). Analisis Tingkat Kepuasan Peserta Didik Dalam Menggunakan E-Learning Di Sekolah Dasar. Jurnal Teknologi Pendidikan, 4(1), $11-15$.

Santi, A., \& Huda, N. (2015). Analisis Kualitas Pelayanan , Kepercayaan dan Nilai Terhadap Kepuasan Peserta Didik Pada Lembaga Pendidikan dan Keterampilan ( LPK ) di Banjarmasin . JWM: Jurnal Wawasan Manajemen, 3(2), 183-199.

Sudodo, Y. (2017). Pengaruh Manajemen Mutu Layanan Terhadap Kepuasan Peserta Didik. Jurnal Ekonomi Dan Bisnis Indonesia, 2(1). https://doi.org/10.37673/jebi.v2i1.51

Sya'diah, N. H., \& Purwanti, E. (2019). Pengaruh Manajemen Administrasi Terhadap Kepuasan Peserta Didik Di Mts Raudlatul Munawwarah Jatirejo. Pengelolaan Pendidikan Dan Pembelajaran Yang Kreatif Dan Inovatif, 80.

Utami, L. A., Ishaq, A., \& Maulidiyah, N. (2018). Analisa Pengaruh Kualitas Website PPDB Terhadap Kepuasan Pengguna. SinkrOn, 3(1), 31. https://doi.org/10.33395/sinkron.v3i1.163 